
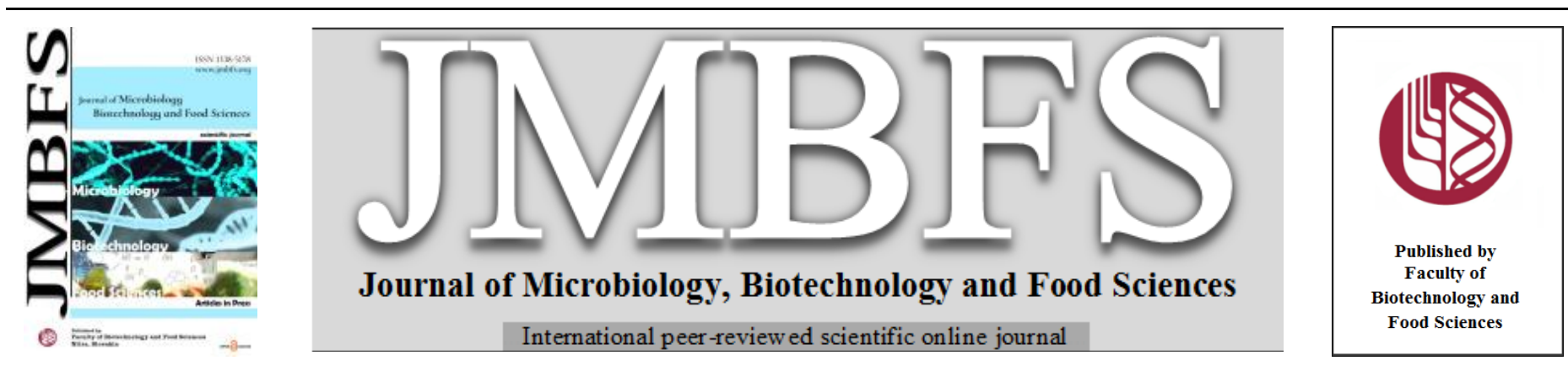

\title{
GENOME-PLASMON INTERACTION EFFECT ON RESISTANCE TO SEPTORIOSIS IN WINTER TRITICUM AESTIVUM L ALLOPLASMATIC LINES
}

\author{
Yongchao Li ${ }^{1,3}$,Volodymyr Vlasenko ${ }^{2}$, Olha Bakumenko ${ }^{2 *}$, Ihor Kovalenko ${ }^{2}$, Vasyl Bilokopytov ${ }^{2}$, Dongxiao Li ${ }^{1,3}$ and Gan $\mathrm{Li}^{1,3}$
}

$\operatorname{Address(es):~}$

${ }^{1}$ School of Life Science and Technology, Henan Institute of Science and Technology, Xinxiang, Henan 453003.

${ }^{2}$ Sumy National Agrarian University, Sumy, G. Kondratyiva Str., 160, Sumy, 40021, Ukraine; Tel.: +38-099-4759310.

${ }^{3}$ Henan International Joint Laboratory of Plant Genetic Improvement and Soil Remediation, Xinxiang, Henan 453003.

*Corresponding author: lady.bakumenko88@gmail.com

https://doi.org/10.55251/jmbfs.5132

\section{ARTICLE INFO}

Received 5. 8. 2021

Revised 5. 10. 2021

Accepted 13. 10. 2021

Published 1. 2. 2022

Regular article open $\partial_{\text {ACCESS }}$

\begin{abstract}
The results of studies on the resistance control to Septoria tritici with alloplasmic lines of bread winter wheat with 14 cytoplasms. The effect of the Triticum aestivum $L$ nuclear genome on its interactions with the cytoplasms of related species on wheat resistance was found out. Analyzing the obtained resistance evaluation results of the genotypes involved in the pathogen Septoria tritici experiment showed the absence of immune forms under the conditions of the Forest-Steppe of Ukraine. The affection intensity of septoria within the control variants over the years was relatively equal from score 5.0 to 4.0 (average - 4.43). Analyzing the nuclear-plasmon effect and genomeplasmon interaction for resistance to septoria, we found out that different sources of alloplasm and the nuclear genome interact differently and provide different resistance effects to septoria. Two nuclear genomes - Donskaia Poluintensivaia and Myronivs'ka Yuvileina were identified with the highest score (5.0). On average, over the years of study, statistically significant data on the response of different plasmotypes to the septoria phytopathogen elicited high variability in both plasmon and genome. The proportion of the genome (p-level $4.97-{ }^{09}$ ) compared with plasmon (p-level $-1.35{ }^{-05}$ ), in the trait variability was almost twice as large. Evaluation of the variability level (according to the results of the sum of squares allocation) caused by the study showed that the factor B input (nuclear genome) was 10.7\%, and the factor A input (cytoplasm) was $28.1 \%$. The interaction of nuclear and cytoplasmic factors accounts $12.1 \%$, and the share of random deviations $-49.1 \%$.
\end{abstract}

Keywords: winter bread wheat; septoria disease; resistance; nuclear genome; alloplasm

\section{INTRODUCTION}

Resistance to septoria disease mainly has polygenic nature and is based on nonallele interaction of two or more genes (different forms of epistasis, complementation and additive effects) (Riaz et al., 2020). Resistance inheritance against septoria disease as a dominant, intermediate or recessive trait is also identified (Herter et al., 2019). Generally, the manifestation of additive gene interaction is the most typical, considering enough frequent effects of dominance. In breeding and genetic studies of wheat, considerable attention is paid to the use of alloplasmic forms. For a number of reasons, polyploid crops are a difficult subject for detailed genetic analysis. The large number of chromosomes and the presence of numerous plexus groups complicate the gene localization and the genetic function detection of individual chromosomes. At the same time, the high ploidy level allows the use of the mutual compensation mechanism for complex cytogenetic manipulations and obtaining viable alloplasmic forms (Kil chevskij $\boldsymbol{e} t$ al., 2010). Literature sources display information as for the efficiency of alloplasmic lines of winter bread wheat varieties in terms of adaptability and confirm the genome and plasmon interaction and the positive effect of alloplasms from Ae. variable, Ae. cylindrica, Ae. squarrosa var. strangulata, T. dicoccoides by adaptability (Simonenko et al., 2000). Researchers at the Institute of Genetics and Cytology of the National Academy of Sciences of Belarus (Minsk) investigated genetic control of plasmon resistance to Septoria nodorum in introgressive bread wheat Transec. According to the analysis of the obtained results, it was found that the high resistance degree of this line was partly due to the recessive gene, which was localized on the $T 4 B S, 4 B L-2 R L$ translocation, or was closely related to it. Although aneuploids are not usually selective in value and they do not have significant superiority, they are used to improve the bread wheat genome, which is one of the most genetically studied plant. Based on standard Chinese Spring aneuploid lines, lines of any genotype that are of some interest to geneticists and breeders can be originated (Lupei, 2000). According to breeders, genetic resistance to septoria has less impact on the resistance manifestation of winter wheat varieties than the impact of weather conditions. Thus, varieties Rapier, Moulin (England), KM 76-92 (Czech Republic), Sandy (USA), selected in 1999 for resistace to septoria, in the course of epiphytic development years of leaf diseases (2000-2001) reduced resistance. As a result, studies have shown that the resistance inheritance in the $\mathrm{F}_{1}$ generation is impacted by the cytoplasm of the mmaternal plant. The of sthrough nuclear apparatus inheritance occurred in $4 \%$ of the analyzed combinations. Resistance to the pathogen was mainly inherited as a dominant trait, or by type of intermediate inheritance (Osmachko et al., 2020).

As far as septoria disease is a common disease in all regions of grain growing both in Ukraine and abroad (Figure 1), the shortage of grain yields with severe pathogen wheat damage increases every year and in some places can reach $40 \%$ (Zhukovsky et al., 2012).


a) 


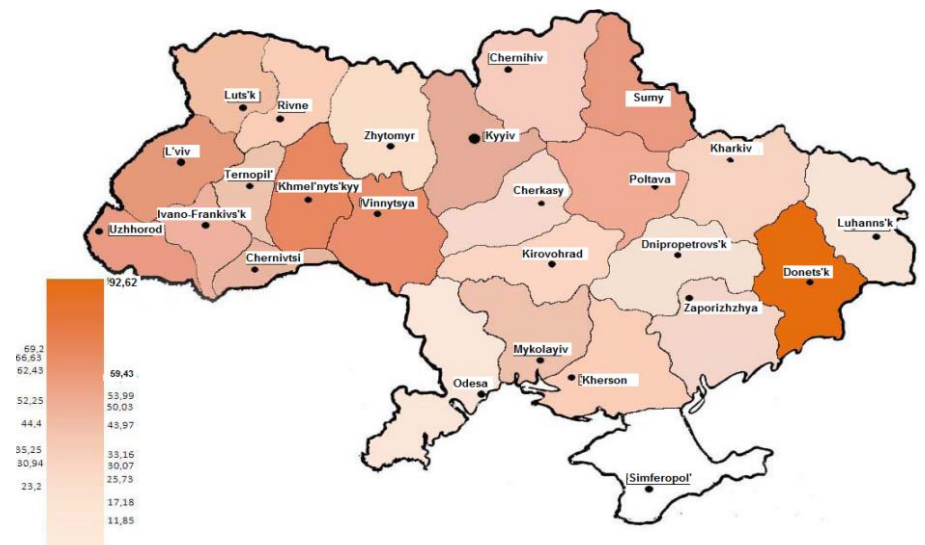

b)

Figure 1 The area average percen mean of affected by septoria disease (a within the global manifestation of the disease, according to CABI; $b$ - within Ukraine, according to Palamarchuk A. 0 et al., 2018)

The half of area percent mean according of regions of Ukraine became as follows: Donetsk - 92.65\%, Khmelnytskii - 69.2\%, Vinnytsia - 66.63\%, Lviv - 62.43\%, Sumy - 60.9\%, Transcarpathian - 59.43\%, Kyiv - 53.99\%, Poltava - 52.25\%, IvanoFrankivsk - 50.03\%, Chernivtsi - 49.3\%, Volyn - 44.4\%, Mykolaiv - 43.97\%, Ternopil - $41.82 \%$, Chernihiv - 35.25\%, Kherson - 33.65\%, Rivne - $33.16 \%$, Kharkiv - $32.3 \%$, Kirovohrad $-30.94 \%$, Zaporizhia region - 30.07\%. Within the world septoria disease scale in Ukraine is moderate (Palamarchuk et al., 2018).

Currently, the study of resistance to septoria disease of alloplasmic wheat, its hybrids with wheat-alien amphiploids and the identification of donorsresistance to Septoria pathogens is important. The aim of our research was to identify and isolate septoria-resistant alloplasmic samples of bread winter wheat and to use them in the selective process as resistance donors. For the final resistance identification of the breeding material we plan to use modern methods of molecular genetics, which will allow to substantiate the sources of resistance genes.

\section{MATERIAL AND METHODS}

Experimental studies were conducted in the breeding crop rotation of Sumy National Agrarian University (SNAU) of the Ministry of Education and Science of Ukraine. Field experiments were performed on the experimental field of the university educational, research and production complex. According to the agrosoil zoning it was located in the forest-steppe district of the region on the northeastern side of the left-bank Forest-Steppe of Ukraine. Geographic coordinates north latitude $50.87^{\circ}$, east longitude $34.77^{\circ}$ (Figure 2). The ground coating is represented by $70 \%$ chernozem typical, deep, medium humus, hard loam on the forest tree with a thickness of the humus layer of $0-75 \mathrm{~cm}$. The average humus content of arable land is $4.1 \%$. The acidity of the soil solution is neutral $-5.9 \mathrm{pH}$ (Kornus et al., 2012). Generally we can confirm that the soil conditions of SNAU experimental field are typical for the zone. It allows to realize the genetically determined potential of the winter wheat studied samples.

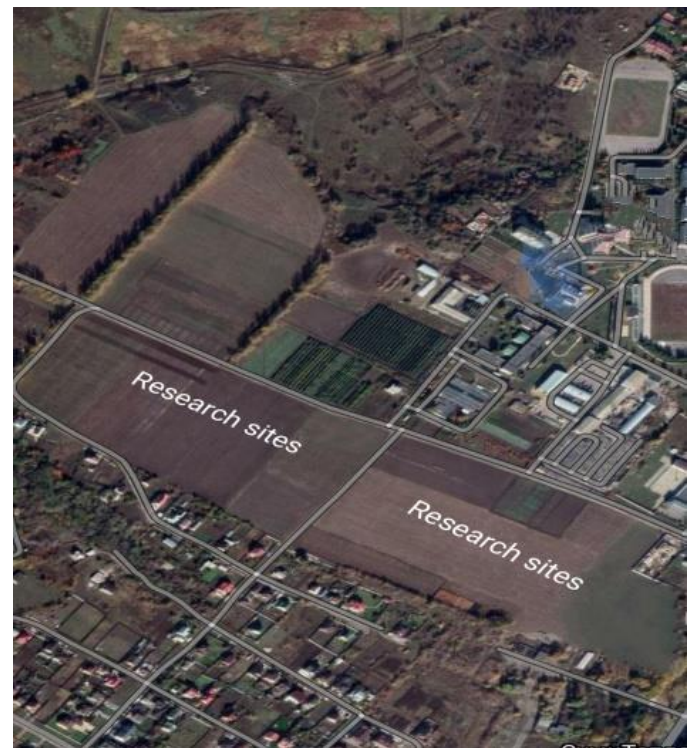

(a)

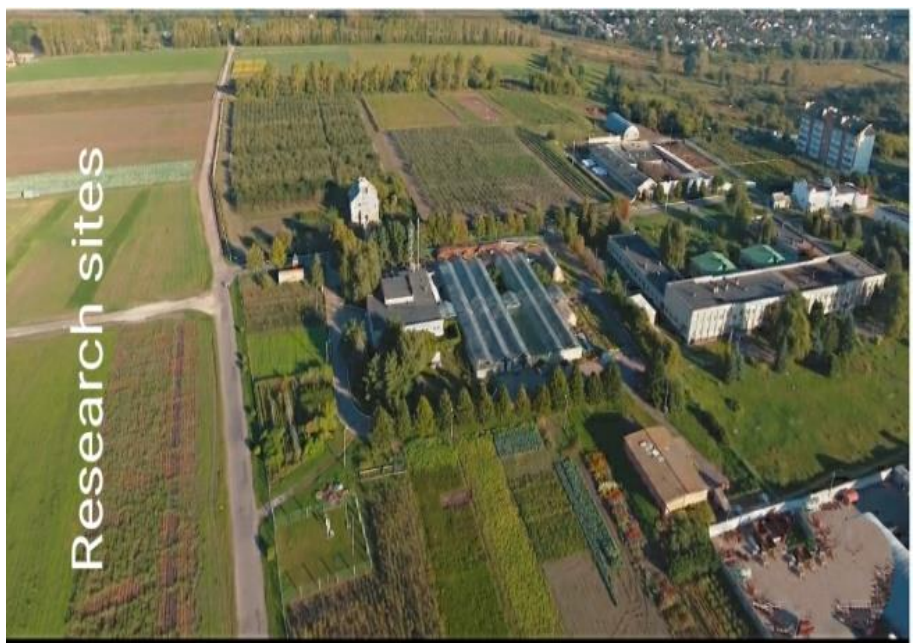

(b)

Figure 2 Map of the study areas and cartograms of the experimental field location: $\mathrm{a}$ - using satellite scan, $\mathrm{b}$ - using photo / video documentation tools

The soils where the research was performed are referred to the second agroclimatic region of Sumy oblast. According to long-term data this region is characterized by a temperate, continental climate with warm summers and not very cold winters with thaws. There are no large water basins in the region that would impact the climate as a whole or its particular elements. The average longterm sum of active temperatures (more than $+5^{\circ} \mathrm{C}$ ) is $3060^{\circ} \mathrm{C}$. The average annual air temperature is $+7.4^{\circ} \mathrm{C}$. According to average long-term data, January and February are the coldest months, and July and August are the warmest months. The absolute minimum of air temperatures most often occurs in January, and the maximum in August. The soil thawing begins in early March and ends in the first decade of April, and the soil warming to $+10^{\circ} \mathrm{C}$ at a depth of $10 \mathrm{~cm}$ occurs in the third decade of April, and in some years is observed in May. Precipitation falls in the form of heavy short-term rains, which are accompanied by strong winds from the west and northwest. The precipitation total is $593 \mathrm{~mm}$. By periods of the year precipitation was classified in the following order: autumn 2019 - $139 \mathrm{~mm}$; winter - $122 \mathrm{~mm}$; spring - $132 \mathrm{~mm}$; summer - $200 \mathrm{~mm}$.

The specimen for the study was a series of alloplasmic lines with 15 cytoplasms: Ae. typical squarrosa; Ae. comosa; Ae. speltoides; Ae. sharonensis; T. dicoccoides spontaneum; T. dicoccum; Ae. cylindrical; Ae. kotschyi; Ae. variable; Ae. ventricosa; Ae. juvenile; Ae. vavilovii; Ae. squarrosa var. strangulata; Hyanaldia villosa. Alloplasmic lines of winter wheat, originated during 1986-1991 (under conditions of breeding greenhouse) by backcross-breeding of five winter wheat genotypes (cultivar MIW - Myronivs'ka 808, Myronivs'ka Yuvileina, EP 9481 line and cultivars from Russia - Donskaia Poluintensvnaia, Kinelskaia 7) with a series of genotypes of spring wheat Chinese Spring on 14 cytoplasms. A series of spring alloplasmic lines was transfered into the genome of bread winter wheat varieties of the V. M Remeslo Myronivka Institute of Wheat (MIW) of the National Academy of Agrarian Sciences of Ukraine - Myronivs'ka Yuvileina, Myronivs'ka 808 and EP 9481line, as well as cultivars from Russia - Donskaia Poluintensivnaia and Kinelskaia 7. Euplasmic lines on these cultivars with cytoplasm of T. aestivum nuclear genome of Chinese Spring were as a control variant.

Laying out of experiments, phenological observations, accounting and screening, harvesting were carried out according to generally accepted methods (Dospekhov, 1985; Tkachyk, 2016; Osmachko et al., 2020). The sample growing practice compares adopted in the area, aimed at growth optimizing and plant development. It includes the timely set of agronomic measures implementation as for tillage, fertilization and application of other agronomic techniques as needed. Samples were sown in optimal time with a manual seeder SR-1 in 3 times repetition. The sowing rate was 5 million units / ha. Plot area $1 \mathrm{~m}^{2}$, predecessor - buckwheat. Plants are harvested by hand in the phase of full ripeness of the grain. Resistance characterization of the alloplasmic lines to septoria disease was performed on a natural infectious background using a variety of infection - Borova. Resistance to the pathogen was determined according to a modified Saari and Prescott scale in the period from the phase of spire shooting to milk-wax ripeness. The resistance degree was appraised on a 9-point scale. Different resistance degrees were characterized by scores from 6 to 9 , and susceptibility - from 1 to 5 . For calculations we took three-year (as the time frequency) the results of resistance evaluation obtained during the period of maximum disease manifestation. The review began with the lower plant stratum. The research was performed using laboratory, field, mathematical and statistical methods. The latter ones were carried out using two-factor dispersion analysis, based on which we found an evaluate of the affect factor on the resistance manifestation to septoria. 


\section{RESULTS AND DISCUSSION}

The development and evolution of technologies for obtaining alloplasmic and cytoplasmic hybrids led to the formation of virtually a whole direction in cytoplasmic genetics - the study of nuclear-cytoplasmic interactions. With the help of these two technologies, created on the basis of experimental approaches, it became possible to obtain alloplasmic and hybrid plants with new combinations of nucleus and organelle not only between phylogenetically close but distant species also. New nuclear-cytoplasmic interactions in such plants proved to be a powerful generator of genetic variability, of both practical and theoretical interest in various fields of knowledge, such as biotechnology, genetics, physiology or molecular biology (Ratushnyak et al., 2012). Crop alloplasmic hybrids with foreign cytoplasms of wild species have many useful morphological, functional or adaptive features and can be used for breeding of new varieties.

Three-year research results of alloplasmic wheat indicate a different rate of response to the pathogen Septoria tritici resistance The research results indicate variation of the index score from 3.67 to 6.00 (Figure 3). The highest resistance was observed in the genomes of Myronivska 808, Donskaia Poluintensivnaia and Myronivs'ka Yuvileina under the positive influence of the plasmon T. dicoccoides spontaneum. The confidence level (p-level) was within 0.02-0.76. It shows that the nuclear genome and plasmon have different effects on plant resistance to the pathogen septoria (Table 1).

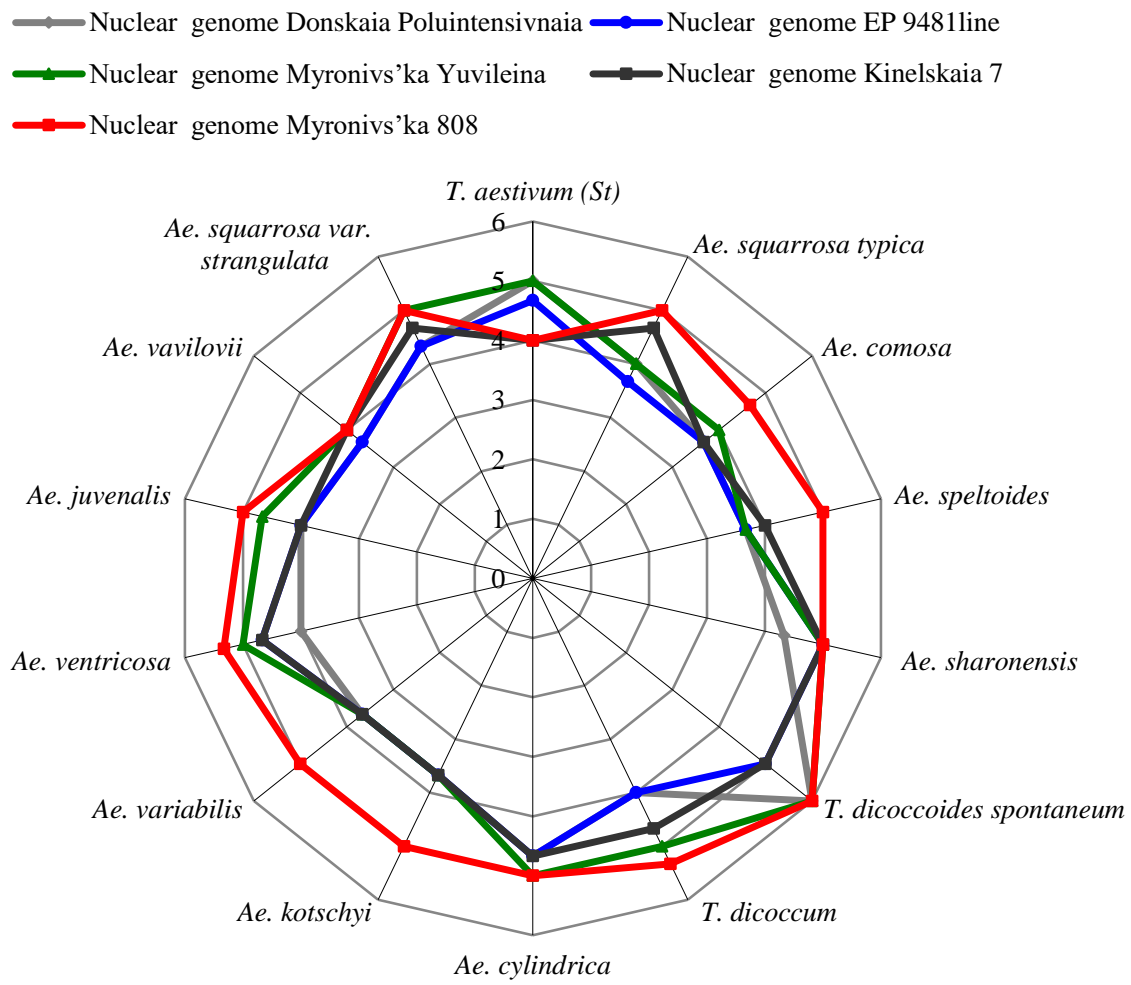

Figure 3 Classification of wheat samples according to septoria resistance

Table 1 Resistance of winter wheat alloplasmic lines to septoria under the conditions of the north-eastern Forest-Steppe of Ukraine (average index of three year researches)

\begin{tabular}{|c|c|c|c|c|c|c|}
\hline \multirow[b]{2}{*}{ Cytoplasm source } & \multicolumn{5}{|c|}{ Nuclear genome $\left(\bar{x} \pm \mathrm{S}^{\bar{x}}\right)$} & \multirow[b]{2}{*}{$\bar{x}$} \\
\hline & 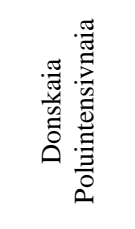 & 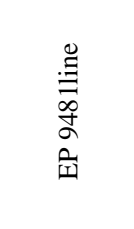 &  & 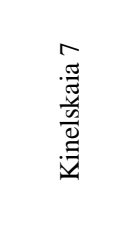 & 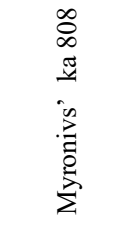 & \\
\hline 1. T. aestivum (control) & $5.00 \pm 0.58$ & $4.67 \pm 0.33$ & $5.00 \pm 0.58$ & $4.00 \pm 0.00$ & $4.00 \pm 0.00$ & 4.53 \\
\hline 2. Ae. squarrosa typica & $4.00 \pm 0.58$ & $3.67 \pm 0.33$ & $4.00 \pm 0.58$ & $4.67 \pm 0.33$ & $5.00 \pm 0.58$ & 4.27 \\
\hline 3. Ae comosa & $3.67 \pm 0.33$ & $3.67 \pm 0.33$ & $4.00 \pm 0.00$ & $3.67 \pm 0.33$ & $4.67 \pm 0.33$ & 3.94 \\
\hline 4.Ae. speltoides & $3.67 \pm 0.33$ & $3.67 \pm 0.33$ & $3.67 \pm 0.33$ & $4.00 \pm 0.58$ & $5.00 \pm 0.58$ & 4.00 \\
\hline 5.Ae. sharonensis & $4.33 \pm 0.33$ & $5.00 \pm 0.58$ & $5.00 \pm 0.58$ & $5.00 \pm 0.58$ & $5.00 \pm 0.58$ & 4.87 \\
\hline 6. T. dicoccoides spontaneum & $6.00 \pm 0.58$ & $5.00 \pm 0.00$ & $6.00 \pm 0.58$ & $5.00 \pm 0.00$ & $6.00 \pm 0.58$ & 5.60 \\
\hline 7.T. dicoccum & $4.00 \pm 0.00$ & $4.00 \pm 0.00$ & $5.00 \pm 0.00$ & $4.67 \pm 0.33$ & $5.33 \pm 0.33$ & 4.60 \\
\hline 8. Ae.cylindrica & $4.67 \pm 0.33$ & $4.67 \pm 0.33$ & $5.00 \pm 0.58$ & $4.67 \pm 0.33$ & $5.00 \pm 0.58$ & 4.80 \\
\hline 9. Ae. kotschyi & $3.67 \pm 0.33$ & $3.67 \pm 0.33$ & $3.67 \pm 0.33$ & $3.67 \pm 0.33$ & $5.00 \pm 0.58$ & 3.94 \\
\hline 10. Ae. variabilis & $3.67 \pm 0.33$ & $3.67 \pm 0.33$ & $3.67 \pm 0.33$ & $3.67 \pm 0.33$ & $5.00 \pm 0.58$ & 3.94 \\
\hline 11. Ae. ventricosa & $4.00 \pm 0.00$ & $4.67 \pm 0.33$ & $5.00 \pm 0.58$ & $4.67 \pm 0.33$ & $5.33 \pm 0.88$ & 4.73 \\
\hline 12. Ae.juvenalis & $4.00 \pm 0.00$ & $4.00 \pm 0.00$ & $4.67 \pm 0.33$ & $4.00 \pm 0.00$ & $5.00 \pm 0.58$ & 4.33 \\
\hline 13. Ae. vavilovii & $3.67 \pm 0.33$ & $3.67 \pm 0.33$ & $4.00 \pm 0.58$ & $4.00 \pm 0.58$ & $4.00 \pm 0.58$ & 3.87 \\
\hline 14. Ae. squarrosa var. strangulata & $4.33 \pm 0.67$ & $4.33 \pm 0.67$ & $5.00 \pm 0.58$ & $4.67 \pm 0.33$ & $5.00 \pm 0.58$ & 4.67 \\
\hline $\bar{x}$ & 4.19 & 4.17 & 4.55 & 4.31 & 4.91 & 4.43 \\
\hline p-level & 0.02 & 0.06 & 0.04 & 0.09 & 0.76 & \\
\hline
\end{tabular}

Legend: $X$-arithmetical mean; $S X$-standard drawback; p-level-confidence level

Analyzing the obtained results of the resistance evaluation involved in the experiment of genotypes to the pathogen $S$. tritici, we note the absence of immune forms under the conditions of the north-eastern Forest-Steppe of Ukraine. The intensity of variety septoria infestation within the control variants over the years was relatively equal from score 5.0 to 4.0 (average -4.53 ). With the highest score (5.0) two nuclear genomes were identified - Donskaia Poluintensivnaia and 
Myronivs'ka Yuvileina. The average resistance score of winter wheat alloplasmic lines to septoria was 4.43. Depending on the cytoplasm and nuclear genome, this index ranged from score 4.17 to 4.91 . Different resistance degrees of were characterized by scores from 6 to 9 , and susceptibility - from 1 to 5 .

Analyzing the nuclear-plasmon effect and genome-plasmon interaction as for resistance to septoria, we see that different sources of alloplasm and the nuclear genome interact differently and provide different effects of resistance to Septoria. The affect intensity of Donskaia Poluintensyvna genome decreased due to the interaction with the plasmon $T$. dicoccoides spontaneum, all other studied alloplasms had a negative effect on the genotype resistance to the disease. Similar resistance index to septoria had a nuclear genome Myronivs'ka Yuvileina, but the interaction with alloplasms was slightly different from Donskaia Poluintensivnaia. T. dicoccoides spontaneum plasmon had a positive effect on resistance to septoria. Myronivska interaction with alloplasms - Ae. sharonensis, T. dicoccum, Ae. cylindrical, Ae. ventricosa, Ae. squarrosa var. Strangulate - did not affect the resistance to the pathogen. That is, a nuclear-cytoplasmic combination of genomes and plasmons took place genetically without deterioration of stability index, which are a kind of bank of genetically valuable properties.

The arithmetical mean (score 4.43) of genotype resistance in the experiment exceeded Line E9481 and had resistance to the pathogen Septoria - (score 4.67). Improvement of the nuclear genome occurred by interaction with plasmons - $T$. dicoccoides spontaneum, Ae. sharonensis.

Kinelskaya 7 and Myronivs'ka 808 genomes had the lowest resistance index to Septoria. However, they were characterized by a much better plasmon gene interaction to disease resistance. There was a positive effect of alloplasms Ae. typical squarrosa, Ae. sharonensis, T. dicoccoides spontaneum, T. dicoccum, Ae. cylindrica, Ae. ventricosa, Ae. squarrosa var. strangulata on Kinelskaia 7 genome resistance to septoria. The positive effect of genome-plasmon interaction was observed in all lines of Myronivs'ka 808 except for interaction with plasmon Ae. vavilovii, which showed a negative or no effect-interaction with all nuclear genomes involved in the experiment as for disease resistance.

The interaction of plasmon $T$. dicoccoides spontaneum with all genotypes of the studied varieties had a stable positive effect on resistance to septoria disease. It is shown by the highest resistance rate in the experiment in samples created with this alloplasm.

The average population mean (score 4.43) and the average genome control index (score 4.53) of pathogen resistance exceeded seven samples of alloplasmic wheat - Ae. sharonensis (score 4.87), T. dicoccoides spontaneum (5.60), T. dicoccum (4.60), Ae. cylindrica (4.80), Ae. ventricosa (4.73), Ae. squarrosa var. strangulate (4.67). Resistance to septoria of Myronivs'ka 808 alloplasmic lines and their hybrids with amphiploid did not differ significantly over the years (p-level - 0.76) Therefore, the effect of alloplasms on resistance to septoria in the above mentioned sample is insignificant.

Thus, on average over the years of research, statistically significant data as for the reaction of different plasmotypes on the phytopathogen of septoria were obtained. Both the plasmon and the genome showed high statistically significant variability. The proportion of the genome ( $\mathrm{p}$-level $-4.97^{-09}$ ), compared with plasmon ( $\mathrm{p}-\mathrm{leve}$ $-1.35^{-05}$ ), in the trait variability was almost twice as large (Table 2).

The variability level evaluiation (according to the results of the sum of squares alloocation) caused by the studied factors revealed the factor B input (nuclear genome) at the level of $10.7 \%$, the factor A input (cytoplasm) was $28.1 \%$. The interaction share of nuclear and cytoplasmic genomes is $12.1 \%$, and the random deviations share is $49.1 \%$. The evaluation of these effects is reliable at p-level from $4.97^{-09}$ to 0.95 .

Table 2 The results of dispersion resistance analysis to septoria of winter wheat alloplasmic lines

\begin{tabular}{|c|c|c|c|c|c|c|c|}
\hline \multirow{2}{*}{ The source variability } & \multirow{2}{*}{$\begin{array}{l}\text { Sum of } \\
\text { squares }\end{array}$} & \multirow{2}{*}{$\begin{array}{l}\text { Degree of } \\
\text { varience }\end{array}$} & \multirow{2}{*}{$\begin{array}{l}\text { Mean } \\
\text { square }\end{array}$} & Fisher & erion & \multirow{2}{*}{ p-level } & \multirow{2}{*}{$\mathrm{LSD}_{05}$} \\
\hline & & & & \multicolumn{2}{|c|}{ actual / tabular } & & \\
\hline Factor A (цитоплазма) & 46.5 & 13 & 3.57 & 6.15 & 1.79 & $4.97^{-09}$ & 0.55 \\
\hline Factor В (ядерний геном) & 17.74 & 4 & 4.44 & 7.63 & 2.43 & $1.35^{-05}$ & 0.32 \\
\hline Interaction $\mathrm{A}$ and $\mathrm{B}$ & 20.12 & 52 & 0.39 & 0.67 & 1.43 & 0.95 & 1.23 \\
\hline Accidental & 81.33 & 140 & 0.58 & - & - & - & - \\
\hline Genaral & 165.69 & 209 & - & - & - & - & - \\
\hline
\end{tabular}

According to the results of resistance genomes ranking depending on the plasmon action, samples were found in all cases that exceed the control (T. aestivum). The number rank indicates its place in according to the size among other values in the list (table 3).



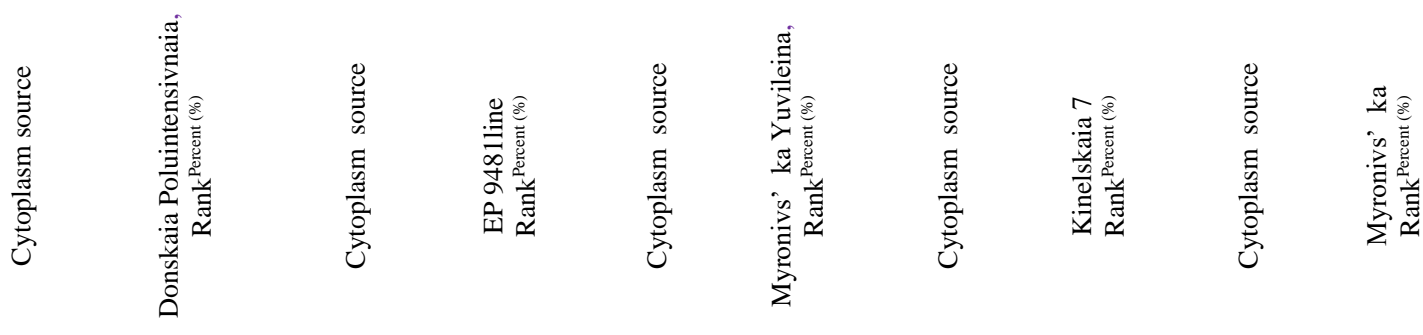

\begin{tabular}{cccccccccc}
\hline $\mathbf{6}$ & $1^{100.0}$ & $\mathbf{5}$ & $1^{92.3}$ & $\mathbf{6}$ & $1^{100.0}$ & $\mathbf{5}$ & $1^{92.3}$ & $\mathbf{6}$ & $1^{100.0}$ \\
\hline $\mathbf{1}$ & $2^{92.3}$ & $\mathbf{6}$ & $1^{92.3}$ & $\mathbf{1}$ & $2^{53.8}$ & $\mathbf{6}$ & $1^{92.3}$ & $2^{84.6}$ \\
\hline $\mathbf{8}$ & $3^{84.6}$ & $\mathbf{1}$ & $3^{69.2}$ & $\mathbf{5}$ & $2^{53.8}$ & $\mathbf{2}$ & $3^{53.8}$ & $2^{84.6}$ \\
\hline $\mathbf{5}$ & $4^{69.2}$ & $\mathbf{8}$ & $3^{69.2}$ & $\mathbf{7}$ & $2^{53.8}$ & $\mathbf{7}$ & $3^{53.8}$ & $\mathbf{2}$ & $4^{23.0}$ \\
\hline $\mathbf{1 4}$ & $4^{69.2}$ & $\mathbf{1 1}$ & $3^{69.2}$ & $\mathbf{8}$ & $2^{53.8}$ & $\mathbf{8}$ & $3^{53.8}$ & $\mathbf{4}$ & $4^{23.0}$ \\
\hline $\mathbf{2}$ & $6^{38.4}$ & $\mathbf{1 4}$ & $6^{61.5}$ & $\mathbf{1 1}$ & $2^{53.8}$ & $\mathbf{1 1}$ & $3^{53.8}$ & $\mathbf{5}$ & $4^{23.0}$ \\
\hline $\mathbf{7}$ & $6^{38.4}$ & $\mathbf{7}$ & $7^{46.1}$ & $\mathbf{1 4}$ & $2^{53.8}$ & $\mathbf{1 4}$ & $3^{53.8}$ & $\mathbf{8}$ & $4^{23.0}$ \\
\hline $\mathbf{1 1}$ & $6^{38.4}$ & $\mathbf{1 2}$ & $7^{46 .}$ & $\mathbf{1 2}$ & $8^{46.1}$ & $\mathbf{1}$ & $8^{23.0}$ & $4^{23.0}$ \\
\hline $\mathbf{1 2}$ & $6^{38.4}$ & $\mathbf{2}$ & $9^{0.0}$ & $\mathbf{2}$ & $9^{23.0}$ & $\mathbf{4}$ & $8^{23.0}$ & $4^{23.0}$ \\
\hline $\mathbf{3}$ & $10^{0.0}$ & $\mathbf{3}$ & $9^{0.0}$ & $\mathbf{3}$ & $9^{23.0}$ & $\mathbf{1 2}$ & $8^{23.0}$ & $4^{23.0}$ & $\mathbf{1 2}$ \\
\hline $\mathbf{4}$ & $10^{0.0}$ & $\mathbf{4}$ & $9^{0.0}$ & $\mathbf{1 3}$ & $9^{23.0}$ & $\mathbf{1 3}$ & $\mathbf{1 4}$ & $4^{23.0}$ \\
\hline $\mathbf{9}$ & $10^{0.0}$ & $\mathbf{9}$ & $9^{0.0}$ & $\mathbf{4}$ & $12^{0.0}$ & $\mathbf{3}$ & $12^{0.0}$ & $\mathbf{3}$ \\
\hline $\mathbf{1 0}$ & $10^{0.0}$ & $\mathbf{1 0}$ & $9^{0.0}$ & $\mathbf{9}$ & $12^{0.0}$ & $\mathbf{9}$ & $12^{0.0}$ & $\mathbf{1}$ \\
\hline $\mathbf{1 3}$ & $10^{0.0}$ & $\mathbf{1 3}$ & $9^{0.0}$ & $\mathbf{1 0}$ & $12^{0.0}$ & $\mathbf{1 0}$ & $12^{0.0}$ & $\mathbf{1 3}$ \\
\hline
\end{tabular}

Positive and negative values are placed in one row so that the smallest absolute value received the first rank, samples with the same values belong to one rank. The rank sum of the positive and negative differences was calculated separately. The zero value was characterized by samples that exceeded the critical value in the calculation. Thus, they had a positive result for the nuclear genome: Donskaia Poluintensivnaia - nine plasmons $100.0-38.4 \%(1,2,6,8,5,14,7,11,12)$; Line E9481 - eight plasmons 92.3-46.1\% (1, 5, 6, 7, 8, 11, 12, 14); Myronivs'ka Yuvileina - eleven plasmons 100.0-23.0\% (1, 2, 3, 5, 6, 7, 8, 11, 12, 13, 14);
Kinelskaia 7 - eleven plasmons 92.3-23.0\% (1, 2, 4, 5, 6, 7, 8, 11, 12, 13, 14; Myronivs'ka 808 - twelve plasmons $100.0-15.3 \%$ ( 2, 4, 5, 6, 7, 8, 9, 10, 3, 11, 12 , 14). All nuclear genomes had a positive result in resistance increasing to septoria using the T. dicoccoides spontaneum cytoplasm and took the first place in rank. As a rule, the interaction of genome $\rightarrow$ plasmon is higher under more severe vegetation conditions of plants (Qingsong et al., 2014). However, we were able to identify a significant of the cytoplasmic factor interaction effect and the nuclear genome, because in combination with different nuclear genomes, the effects of 
cytoplasms were multidirectional. In our experiment, the influence share of the nuclear and cytoplasmic genome interaction was at 95\% (p-level 0.95). In general, the winter wheat genome according to the statistical characteristics of the trait average parameters does not significantly reduce resistance to septoria under the impact of foreign cytoplasms. Once again it testifies the specificity of the plasmon interaction with different genotypes.

Under the conditions of Belarus, sets of spring alloplasmic lines of bread wheat with a Chinese Spring nucleus are similar to our experiments showed the cytoplasms influence of some species of Triticum and Aegilops on certain economically important features. Scientists found a strong inhibitory effect of Aeloplasm Ae. juvenalis, Ae. crassa and Ae. vavilovii on seed attachment, and cytoplasm Ae. Sharonensis for most of the studied signs (Silkova et al., 1984).

In studies of alloplasmic lines series of Novosybirska 67 cultivar, the effect of cytoplasmic substitution on salt resistance was revealed. Lines from the cytoplasm of Triticum sphaerococcum, $T$. spelta and T. persicum were inferior to the original variety in salt stress resistance, and lines from the cytoplasm of $T$. dicoccum, $T$. diccocoides, Aegilops cylindrica and Ae. squarrosa ssp. typica significantly left behind the father on the studied trait (Koval, 1994).

Often the effects of alloplasms are multidirectional. Alloplasm from Ae. ventricosa negatively affects a number of morphobiological indicators, the regularity of meiosis, does not show significant effects on winter and frost resistance (Sechnyak, 2010). However, it has a positive effect on resistance to powdery mildew and brown rust (Vlasenko et al., 2012). All cases, the essential role of the nuclear genome and nuclear-plasma interactions is revealed, as evidenced by the materials of our research.

Differences between alloplasmic lines and control in Chinese scientists studies indicated a beneficial effect of Aegilops crassa cytoplasm on wheat. In general, the agronomic indicators of alloplasmic lines were higher than the efficiency of alloplasmic control. Under the conditions of northern China, a number of useful genetic traits were identified, such as high yields, good quality, and salt resistance. A new hybrid cultivar "Xiaoshan 2134" was originated, the yield heterosis of which was $13.9 \%$, and the yield was at least $20 \%$ higher than in the control variety. The results of these studies indicate that the cytoplasm of Aegilops crassa can expand the genetic base of wheat and improve its performance (Liu et al., 2002). Septoria disease is a disease caused by imperfect fungi of the genus Septoria Septoria tritici Rob. et Desm., Septoria graminum Desm. is the most common for winter wheat. They mainly affects the leaves and leaf axil, and Septoria nodorum Berk., which affects all aboveground organs, including wheatears (Kolomiets $\boldsymbol{e}$ al., 1999). In Ukraine septoria disease is found almost everywhere, Septoria tritici is observed in all growing areas, and Septoria nodorum and Septoria graminum is in Forest-Steppe and Polissya zones (Borzykh, 2015; Bushulyan, 2003). Winter wheat screening on varietal plots and individual farms of Poltava, Cherkasy, Kyiv, Vinnytsia and Ternopil regions made it possible to find out that under the ForestSteppe conditions septoria is widespread and manifests itself annually. However, the number of affected plants and the degree of disease development over the years are different.

Depending on the ecological zone, which is characterized by certain climatic conditions, in some countries one species of pathogen is widespread and dominates, in others - another, or several pathogens simultaneously. For example in Israel the main causative agent of wheat septoria is Septoria tritici (Perello $\boldsymbol{e}$ al., 1991), in Sweden - Stagonospora nodorum, and in England, Wales, France, Denmark, Germany, Western Australia - both species simultaneously (Shrewry $\boldsymbol{e}$ al., 2001). Septoria disease is also observed in crops in most part of Europe, America, even Australia and Africa (Brown and Rosielle, 1980). The septoria pathogens were found in all regions of Algeria where wheat is grown. The disease is a source of serious damage to susceptible varieties (Harrat and Bouznad, 2018).

Currently, resistant wheat varieties to septoria have not been identified, but there

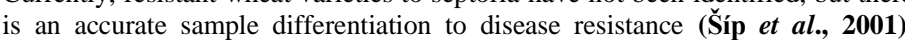
According to the morphotype, tall or medium-sized forms, late-ripening, anemone, with an intense waxy coating on the plant are more resistant to septoria (Chernyaeva et al., 2012). Harmfulness of septoria leads to a decrease in the assimilation surface, premature leaves and plants drying, fragility of stems, poo ear development, premature ripening of bread, reduced grain yield and deterioration of its sowing and technological qualities (Sanin et al., 2015). Yield losses per affection can reach up to $40 \%$. Today, a number of Septoria (Stb) resistance genes have been identified: Stb1 - Stb12, StbAc1 and StbAc2 (Zhukovsky et al., 2012). According to gross data (Rima et al., 2015), the first three genes - Stb1-Stb3 were identified by R. E. Wilson in 1985, Stb4 - by O. C. Somasco in 1990. In 2001, L. S. Arraiano reported the discovery of the Stb5 gene, whose genetic source of resistance is Ae. tauschii, and information from P. A Brading and other authors about the detection of Stb6. Genes with constant symbols Stb7-Stb12, StbAc1 and StbAc2 were identified (McIntosh et al., 2006). Resistance sources of cultivated wheat to pathogens are its related species (Triticale, Triticum timopheevii, T. fungicidum, T. monococcum, T. boeoticum, $T$. kiharae, T. urartu, T. zhukovskui, T. tauschii) and wild relatives (Agropyrun elongatum, Aegilops sguarrosa, Ae. Speltoides, Ae. Sharonensis), from which resistance is transferred to cultivars by interspecific and remote hybridization (Sukhomud and Lyubich, 2013; Bushulyan, 2013)
Researchers of Uman National University of Horticulture studied ecologically remote forms (119 samples) of bread winter wheat and confirmed that there were no varieties that are completely resistant to septoria today. The affection intensity of selected samples by septoria over the years was relatively adjusted. Plants of samples 3872 and 6151 had the highest resistance to the pathogen (at the level of $7.0 \%$ (score 8). Plants of 4075 and 6254 numbers were characterized by significantly lower resistance in the group. Other originated forms had significantly lower resistance to septoria, compared to the materials and the standard variety (Ryabovol et al., 2019).

In European countries, the cultivar of Except winter bread wheat is widely used in breeding practice. It was selected as a result of careful study and selection of all local varieties and was characterized by increased resistance to septoria leaf spo (Shrewry et al., 2001). According to studies by Ukrainian breeders, Atlas 66, Tuller (USA), as well as Palur, Carsten 6 (Germany) (Kovalyshyna et al., 2017), Rapier, Moulin (England), Sandy, Stephe NS, GENE, MADSAN (the USA) (Le Henaff et al., 2006 ), AC-182, Perlyna Lisostepu, Myronivs'ka 67, Myronivs'ka 68 , Brigadier, Hussar, Wakefield, Delta (Afanasieva et al., 2012; Petrenkova, 2006) have a high resistance level to the main pathogens Septoria tritici and Septoria nodorum. However, high resistance, except for separate samples, is almost not found out.

In general, all possible variants of nuclear-cytoplasmic hybrids are a kind of genetically valuable bank of properties, including resistance to septoria. Therefore, it is quite natural that genetic collections of wheat alloplasmic lines in Japan (Tsunewaki et al., 1976) and barley in Belarus (Sychjova et al., 1998) were created from them. Alloplasmas and hybrid cytoplasms, especially between of the phylogenetically remout taxon, are model objects for basic research because scientists are always interested in the scientific facts that answer such questions: of what phenotypic, physiological, or biochemical traits the nuclear genome is responsible for.

Technology of nuclear genome replacement, which helps to obtain alloplasmic or nuclear-cytoplasmic hybrids, began to be used by researchers for higher plants in the twentieth century (Ratushnyak and Kochevenko, 2012). Part of the economically valuable traits that appear in the process of crossing and moving nuclear genomes, later began to be used for the selection of new crop varieties and hybrids (Palilova $\boldsymbol{e t}$ al. 2005). Studies of nuclear-cytoplasmic interactions have helped to understand better the role of the plant cytoplasmic genome, as the importance of the nuclear genome was somewhat over-estimated over a period of genetics development. After the DNA discovery in plastids and mitochondria, it was concluded that cytoplasmic heredity is the heredity by which genes located not only in the cytoplasm but also in cell organelles mitochondria and plastids are inherited. The quantitative proportion of genomes in plasmons was less than $1 \%$. However, evaluating the effect degree of foreign cytoplasms on the formation of a number of important quantitative traits in nuclear cytoplasmic hybrids of wheat and wild wheat, we found that about $30 \%$ of the total genetic variability in such plants may be due to organelle genes (Tsunewaki et al., 1996). That is why the cytoplasmic factor is given such a significant role in plant species (Postel and Touzet, 2020)

From the literature sources analysis we see that in the world genofond there is a smal number of genotypes resistant to septoria spots. Result-oriented work is being done to create varieties with a sign of resistance and their introduction into production. It should reduce infection and hold the emergence of new pathogen races. At present, modern methods, in particular biotechnological (cultivation and selection on selective medium), are used in breeding for septoria resistance. Pure culture fungi obtained on agar as well as on culture filtrates are used as selective medium (Morgun 2016). However, in progress the winter wheat varieties are not highly resistant to septoria. Therefore, it is necessary to work result-oriented to find resistance sources to create varieties resistant to pathogens that will reduce infection and inhibit the emergence of new pathogenraces. Additionally, the chance of our further research is the involvement of modern molecular genetics methods, which will reasonably confirm the sources of resistance genes.

\section{CONCLUSION}

The cytoplasmic effect in wheat is well studied, but it remains an urgent problem in breeding, and therefore requires constant research on the cytoplasmdiversity in modern wheat genotypes, genome interaction with plasmon and adaptation to specific environmental conditions. In the breeding as for disease resistance, it is important to identify plasmons that cause improved variety resistance parameters. The effect of the Triticum aestivum $L$. nuclear genome on the wheat resistance to septoria disease when it interacts with 14 cytoplasms of related species (Aegilops squarrosa typica; Aegilops comosa; Aegilops speltoides; Aegilops sharonensis; Ae diloccoidsum spontaneum; T. dicoccoides spontaund; T. kotschyi; Aegilops variabilis; Aegilops ventricosa; Aegilops juvenalis; Aegilops vavilovii; Aegilops squarrosa var. strangulata) is found out in the study. Considering the average resistance index to septoria, it should be noted that depending on the nuclear genome rate, there were both: resistance improvement or reduction. The rank change of nuclear genomes and the indicator approximation to the average value was found in Donskaia Poluintensivnaia, Line E9481, Myronivs'ka Yuvileina which on average showed the resistance decrease to septoria, but Myronivs'ka 808, Kinelskaia 7 showed the resistance increase.

According to the results of the analysis of nuclear-plasmonic influence and genome-plasmon interaction on septoria resistance we made sure that different 
sources of alloplasm and nuclear genome interact differently and provided different resistance effects to septoria disease. Two nuclear genomes: Donskaia Poluintensivnaia and Myronivs'ka Yuvileina were identified with the highest score (5.0).

In the genetic system of nuclear-cytoplasmic relations according to septoria resistance, hybrids of bread spring wheat Chinese Spring alloplasmic lines with different genotypes of bread winter wheat were allocated as follows: factor B (nuclear genome) was 10.7\%; and factor A (cytoplasm) - 28.1\%; interaction of nuclear (B) and cytoplasmic (A) factors $12.1 \%$; the share of random deviations is $49.1 \%$. It should be noted that such results may be characteristic of this series of alloplasmic lines and to some extent subjectively reflect the effect of different plasma types on the hybrid resistance with their participation.

Today, it is necessary to work result-oriented to find resistance sources to create varieties resistant to pathogens that will reduce infection and inhibit the emergence of new pathogenraces. Additionally, the chance of our further research is the involvement of modern molecular genetics methods, which will reasonably confirm the sources of resistance genes.

Acknowledgments: This work was supported by Cooperation and exchange project between governments of China and Ukraine (CU03-14).

\section{REFERENCES}

Riaz, A., Kock Appelgren, P., Hehir, J., Kang, J., Meade, F., Cockram, J., Milbourne, D., Spink, J., Mullins, E. \& Byrne, S. (2020). Genetic Analysis Using a Multi-Parent Wheat Population Identifies Novel Sources of Septoria Tritici Blotch Resistance. Genes, 11, 887. http://dx.doi.org/10.3390/genes11080887

Herter, C. P., Ebmeyer, E., Kollers, S. et al. (2019). Accuracy of Within-and Among-Family Genomic Prediction for Fusarium Head Blight and Septoria Tritici Blotch in Winter Wheat. Theor Appl Genet, 132, 1121-1135. http://dx.doi.org/10.1007/s00122-018-3264-6

Kil`chevskij, A. \& Khoty`leva, L. (2010). Henetycheskye Principles of Breeding of Plants. Minsk : Belorusskaya nauka, 2, 579.

Simonenko, V.K., Hangildin, V.V. \& Vlasenko, V.A. (2000). Influence of the Genome of the Variety on the Adaptive Features of Alloplasmic Lines of Winter Wheat. Cytology and Genetics, 34, 21-27: https://cutt.ly/fQzRJ7P

Lupei, A.Yu., Voluevich, E.A. \& Buloichik, A.A. (2000). Effect of Plasmon Inheritance of Resistance to Septoria nodorum Berk. in Bread Wheat. Cytology and Genetics, 3, 9, 15-20.

Osmachko, O.M., Vlasenko, V.A, Bakumenko, O.M. \& Bilokopytov, V.I. (2020). Characteristics of Immunity to Leaf Diseases of Winter Wheat Samples Under the Conditions of the North-East Forest Steppe of Ukraine. Regulatory Mechanisms in Biosystems, 11(1), 45-53. http://dx.doi.org/10.15421/022006

Zhukovsky, A.G., Iliyuk, A.G., Buga, S.F., Sklimenok, N.A., Kremneva, O.Y., Volkova, G.V. \& Gudoshnikova, E.S. (2012). Septoria Spot (Septoria spp.) an Yellow Leaf Spot (Pyrenophora tritici-repentis) Affection of Winter Whea Cultivars in Belarus and North Caucasian Region of Russia. Scientific Journal of KubSAU, 80 (60), 52-60 : https://cutt.ly/KQxkmLo

Palamarchuk, A., Rubezhniak, I. \& Chaika, V. (2018). Incidence of winter whea diseases in Ukraine. Biological Resources and Nature Management, 10, 3-4, 64 71. http://dx.doi.org/10.31548/bio2018.03.008

Kornus, A. (2012). The Land Resource State Evaluation of Sumy Area. Rational Use of Nature and Nature Protection, Proceedings, 1, 215-219.

Dospekhov, B.A. (1985). Field Experiment Technique, Moscow, Agropromizdat, 352 : https://mf.bmstu.ru/info/faculty/lt/caf/lt1/soil_books/uchebnik9.pdf

Tkachyk, S.O., Leschuk, N.V. \& Prysyazhnyuk, O.I. (2016). Methods of Qualification Examination of Plant Varieties for Suitability for Distribution in Ukraine. The General Part. Ukrainian Institute of Plant Variety Examination, Vinnytsia, $120:$ https://sops.gov.ua/uploads/page/5b7e5c0ed8332.pdf

Osmachko, O.M., Vlasenko, V.A. \& Bakumenko, O.M. (2020). Methodical recommendations for the selection of wheat lines with group resistance to diseases that are the transmitters of wheat-rye translocations, Sumy, Sumy National Agrarian University, 154 : https://cutt.ly/kQxiNIa

Ratushnyak, Y.I. \& Kochevenko, A.S. (2012). Effects of Alloplasmic Interaction in the Higher Plant Reciprocal Cybrids, Biotechnology, 5, 1, 18-32 https://cyberleninka.ru/article/n/effekty-alloplazmaticheskih-vzaimodeystviy-uretsiproknyh-tsibridov-vysshih-rasteniy/viewer

Qingsong, B., Gaisheng, Z., Shoucai, M. \& Junwei, W. (2014). Cytoplasmic Effects on DNA Methylation Between Male Sterile Lines and the Maintainer in Wheat (Triticum aestivum L.). Gene, 549, 1, 192-197. http://dx.doi.org/10.1016/j.gene.2014.01.001

Silkova, T.A. (1984). Influence of foreign cytoplasm on the manifestation of critically important parameters in allaplasmic lines of soft mildew. News from the National Academy of Sciences of Belarus. Bial series, 3, 39-43.

Koval, V.S. (1994). Influence of Cytoplasm of Some Types of Cereals on Salt Tolerance of Common Wheat. Genetics, 72.

Sechnyak, A.L. \& Golub, J.V. (2010). Daptibility of Wheat Alloplasmatic Lines at Hybridization. Cytology and Genetics, 1, 30-35 http://dspace.nbuv.gov.ua/handle/123456789/66678
Vlasenko, V.A., Kochmarskyi, V.S., Koliuchyi, V.T., Kolomiiets, L.A., Khomenko, S.O. \& Solona, V.Y. (2012). Breeding Evolution of Myroniv Wheat. Myronivka, 330

Liu, C.G., Wu, Y.W., Hou, H. et al. (2002). Value and Utilization of Alloplasmic Common Wheats With Aegilops Crassa Cytoplasm. Plant Breed, 121, 5, 407-410. http://dx.doi.org/10.1046/j.1439-0523.2002.755374.x

Kolomiets, S. (1999). Populations of Septoria SPP. Affecting Winter Wheat in the Forest-Steppe Zone of the Ukraine. Septoria and Stagonospora Diseases of Cereals: A Compilation of Global Research : Proceedings of the Fifth International Septoria Workshop, September 20-24. CIMMYT, Mexico, 32-33 https://cutt.ly/hQxz8ky

Borzykh, O. (2015). Plant diseases of the main field crops in agrocenosis of Ukraine. Biological Resources and Nature Management, 7, 1-2, 183-189 http://journals.uran.ua/index.php/2078-9912/article/download/113874/108434 Bushulyan, M.A. (2003). The Original Material for Breeding Winter Wheat varieTies with Resistance to Septoria Tritici Blotch (Septoria tritici Rob.ex Desm.) in the Conditions of the South of Ukraine, Odessa, $117:$ https://cutt.ly/uQxxtne

Perello, A.E., Cordo, C.A., Arriaga, H.O. \& Alippi, H.E. (1991). Variation in virulence of Septoria tritici Rob ex Desm Isolates on Wheat. Agronomie January, 571-579. http://dx.doi.org/10.1051/agro:19910705

Shrewry, P.R., Bonjean, A.P. \& Angus, W.J. (2001). The World Wheat Book. A History of Wheat Breeding. Annals of Botany, 88, 5, 953-955. http://dx.doi.org/10.1006/anbo.2001.1537

Brown, A.C. \& Rosielle, A.A. (1980). Prospects for Control of Septoria. J. Agr West Austral, 21, 8-11

https://researchlibrary.agric.wa.gov.au/journal_agriculture4/vol21/iss 1/3

Harrat, W. \& Bouznad, Z. (2018). Prevalence, Cultural and Pathogenic Characterization of Zymoseptoria Tritici, Agent of Wheat Septoria Leaf Blotch, in Algeria. African Journal of Agricultural Research, 13 (40), 2146-2153. http://dx.doi.org/10.5897/AJAR2018.13434

Š́p, V., Stuchlíková, E. \& Chrpová, J. (2001). The Response of Selected Winter Wheat Cultivars to Artificial Infection with Septoria Tritici Under Field Conditions. Czech Journal of Genetics and Plant Breeding, 37, 73-81 https://agris.fao.org/agris-search/search.do?recordID=CZ2002000008

Chernyaeva, I.M., Luchna, I.S., Petrencova, V.P. \& Kochurov, Ya.V. (2012). New Sources for Resistance of Soft Winter Wheat to Deseases in the North-Eastern Part of Forest-Steppe of Ukraine. Genetic Resources of Plants, 10/11, 132-139 http://irbis-nbuv.gov.ua/cgi-

bin/irbis_nbuv/cgiirbis_64.exe?C21COM=2\&I21DBN=UJRN\&P21DBN=UJRN \&IMAGE FILE DOWNLOAD=1\&Image file name=PDF/grr 2012 10-

11_17.pdf

Sanin, S.S., Korneva, L.H. \& Polyakova, T.M. (2015). Prediction of the Risk of Epiphytosis of Septoria of Leaves and Ears of Wheat. Plant Protection and Quarantine, 33-36 : https://cyberleninka.ru/article/n/prognoz-riska-razvitiyaepifitotiy-septorioza-listiev-i-kolosa-pshenitsy/viewer

Thapa, R., Brown-Guedira, G., Ohm, H. W., Wise, K. \& Goodwin, S. B. (2015) Determining the Order of Resistance Genes Qsng-3BS, Fhb1 and Sr2 and Combining Them in Coupling on Wheat Chromosome 3BS. Advances in Wheat Genetics: From Genome to Field Proceedings of the 12th International Wheat Genetics Symposium, 319-322. http://dx.doi.org/10.1007/978-4-431-55675-6

McIntosh, R.A., Devos, K.M., Dubcovsky, J., Rogers, W.J., Morris, C.F., Appels R. \& Anderson, O.A. (2006). Catalogue of Gene Symbols for Wheat: Supplement : https://shigen.nig.ac.jp/wheat/komugi/genes/macgene/supplement2006.pdf

Sukhomud, O.H. \& Lyubich, V.V. (2013). The Degree of Manifestation and Prevalence of Septoria of Winter Wheat Leaves Depending on the Variety. Breeding and Seed, 103, 248-255. http://dx.doi.org/10.30835/2413 7510.2013.54130

Bushulyan, M.A. (2013). Characteristic of Winter Wheat Varieties on Features, Which Cause Resistance-Susceptibility to Septoria Tritici in the Steppe of Ukraine The Bulletin of Kharkiv National Agrarian University. Series "Phytopathology and Entomology", 10, 50-53: https://knau.kharkov.ua/vfn201822.html

Ryabovol, YAS, Ryabovol, L.O. \& Diordieva, I.P. (2019). Disease Resistance of Soft Winter Wheat Specimens Created by Hybridization of Geographically Distant Forms. Foothill and Mountain Agriculture and Animal Husbandry, 65, 124-133. http://dx.doi.org/10.32636/01308521.2019-(65)-11

Kovalyshyna, H.M., Dmytrenko, Yu.M., Demydov, O.A., Mukha, T.I. \& Murashko, L.A. (2017). Winter Wheat Breeding for Disease Resistance. Crop and
Soil
Science,
269
99-110

http://journals.nubip.edu.ua/index.php/Agronomija/article/view/9670/8647

Le Henaff, G., Leroux, P., Delos, M. \& Walker, A. (2006). Field Efficacy and Resistance to Fungicides in Septoria Tritici on Winter Wheat (en). Phytoma, $L a$ Défense Des Végétaux, 599, 15-19 : http://pascalfrancis.inist.fr/vibad/index.php?action=getRecordDetail\&idt $=18344542$

Afanasieva, O., Boyko, I., Dovgal, Z., Sokolovska, M. and Golosna, L. (2012) Sources of Resistance of Winter Wheat to the Basic Causal Organisms Fungal Diseases. Plant Protection and Quarantine, 58, 9-16 : http://www.irbisnbuv.gov.ua/cgi-

bin/irbis_nbuv/cgiirbis_64.exe?C21COM=2\&I21DBN=UJRN\&P21DBN=UJRN \&IMAGE_FILE_DOWNLOAD=1\&Image_file_name=PDF/Zikr_2012_58_4.pd 
Petrenkova, V.P. (2006) Current State and Problems of Solving Plant Stability. Optimization of Integrated Field Crop Protection: Handbook, Kharkiv, 4-5.

Tsunewaki, K., Mukai, Y., Ryu Endo, T., Tsuji, S. \& Murata, M. (1976). Genetic Diversity of the Cytoplasm in Triticum and Aegilops. The Japanese Journal of Genetics, 51, 3, 175-191. http://dx.doi.org/10.1266/jig.51.175

Sychjova, I.M., Triboush, S.O., Danilenko, N.G. \& Davydenko, O.G. (1998). The Collection of Alloand Isoplasmic Barley Lines with PDRF-Studied Mitochondrial DNA. Barley Genet. Newslet, 28, 9-11.

Ratushnyak, Y.I. \& Kochevenko, A.S. (2012). Effects of Alloplasmic Interactions in the Higher Plant Reciprocal Cybrids. Biotechnology, 5, 1, 18-32.

Palilova, A.N., Orlov, P.A. \& Voluevich, E.A. (2005). Basic and Applied Problems of Nuclear-Cytoplasmic Genetic Systems Interactions in Plants. VOGiS Bulletin, 9, 4, 499-504

http://www.bionet.nsc.ru/vogis/pict_pdf/2005/t9 4/vestnik 944 06.pdf

Tsunewaki, K., Wang, G. \& Matsuoka, Y. (1996). Plasmon Analysis of Triticum (wheat) and Aegilops. I. Production of Alloplasmic Common Wheats and Their Fertility. Genes Genet. Syst. 71, 5, 293-311. http://dx.doi.org/10.1266/ggs.71.293

Postel, Z. \& Touzet, P. (2020). Cytonuclear Genetic Incompatibilities in Plant Speciation. Plants, 9, 487. http://dx.doi.org/10.3390/plants9040487

Morgun, V.V., Dubrovna, O.V. \& Morgun, B.V. (2016). The Modern Biotechnologies of Producing Wheat Plants Resistant to Stresses. Plant Physiology and Genetics, 48, 3, 196-214. https://doi.org/10.15407/frg2016.03.196 